\title{
MENUMBUHKAN KECERDASAN BAHASA DAN KARAKTER BANGSA MELALUI AKTIVITAS MENDONGENG PADA SISWA SEKOLAH DASAR
}

\author{
Winda Dwi Hudhana ${ }^{1}$, Dilla Fadhillah ${ }^{2}$ \\ Universitas Muhammadiyah Tangerang \\ windhana89@gmail.com
}

\begin{abstract}
Abstrak
Aktivitas mendongeng merupakan budaya bercerita yang telah dilakukan dari zaman dahulu dan merupakan tradisi turun temurun. Dongeng mengandung kisah-kisah yang di dalamnya terdapat pembelajaran mengenai norma dan nilai dalam kehidupan. Pada pembelajaran karya sastra di Sekolah Dasar, mendongeng merupakan pembelajaran yang dapat melatih kebahasaan anak dan dapat memberikan pembelajaran norma dan nilai yang sangat tepat. Kesadaran mengenai berbahasa yang baik dan pendidikan karakter sangatlah penting dan harus dilakukan secara tepat, dalam aktivitas mendongeng diharapkan para orang tua dan guru tidak hanya melakukan aktivitas mendongeng semata namun memberikan bimbingan kebahasaan dan karakter yang terdapat dalam dongeng. Maka anak selain mendapatkan pendidikan kebahasaan, juga mendapatkan pendidikan karakter sekaligus.
\end{abstract}

Kata Kunci : Mendongeng, Karakter Bangsa, Siswa SD

\section{A. Pendahuluan}

Masyarakat Indonesia saat ini telah terhipnotis oleh kemajuan zaman dan kecanggihan teknologi. Para orang tua saat ini lebih mempercayakan teknologi untuk mengasuh anaknya, misalnya orang tua lebih merelakan anaknya bermain gadget atau handphone daripada membacakan cerita-cerita yang biasa dilakukan oleh masyarakat zaman dahulu. Hal tersebut berdampak pada perkembangan anak secara emosional dan moral. Tiada heran kalau saat ini banyak berkembang kriminalitas di kalangan remaja yang disebabkan maraknya penggunaan gadget dan handphone. Banyak terjadi bulliying, pemerkosaan, pencurian, bahkan sampai pembunuhan yang dilakukan oleh anak-anak seusia Sekolah Dasar. Perilaku tersebut didasari kebiasaan anak melihat konten-konten website ataupu media sosial yang seharusnya tidak dilihat oleh anak namun dapat bebas dilihat oleh anak, terlebih anak-anak yang masih berusia balita. Padahal pada masa balita merupakan masa emas anak yang mana tingkat imitasi anak 
masih tinggi dan ingatan jangka panjang anak sangat tinggi. Saat ini tidaklah heran bahwa anak Indonesia telah mengalami degradasi karakter.

Peranan kisah tradisional telah tergeser oleh peranan gadget dan handphone. Oleh karena, orang tua yang sibuk bekerja tidak memiliki banyak waktu untuk menemani anak-anaknya bermain. Setelah selesai bekerja, mereka akan merasa kelelahan dan enggan untuk menemani anaknya bermain. Maka, gadget dan handphone menjadi satusatunya pilihan para orang tua yang memiliki banyak variasi permainan sehingga tidak perlu membelikan banyak mainan. Namun, berakibat anak menjadi kecanduan pada gadget dan handphone sehingga ia tidak mau dipisahkan dengan alat tersebut.

Penggunaan gadget dan handphone ini membuat anak menyendiri dan sulit untuk bersosialisasi dengan teman sebaya. Hal tersebut berakibat bahwa perkembangan bahasa anak menjadi terhambat. Anak menjadi sulit berkomunikasi maupun sulit mengatakan maksud dan tujuannya dalam berinteraksi. Di sinilah peran seorang guru dalam menumbuhkan kembali kecerdasan bahasa dan karakter siswa yang mungkin semakin menurun. Guru di sekolah merupakan orang tua kedua, maka guru harus dapat membimbing siswanya dalam berperilaku. Oleh karena tugas guru tidak hanya mengajarkan ilmu namun mendidik agar selain cerdas berbahasa juga berkarakter kuat. Pendidikan karakter dalam hal ini ditujukan unruk mengembangkan dan membentuk sikap, watak dan budi pekerti yang luhur sehingga sangat penting dalam kehidupan.

Menurut Hudhana (2015:121) bahwa beberapa metode yang dapat dilakukan untuk menanamkan karakter adalah mendongeng, bercerita kembali dan teater. Salah satu strategi praktis yang dapat dilakukan guru dalam menanamkan karakter dan kecerdasan berbahasa yaitu melakukan aktivitas mendongeng. Mendongeng merupakan upaya membantu perkembangan dan potensi seorang anak karena anak-anak merupakan masa di mana mereka berkembang dengan cara imitasi. Ketika anak mengimitasi perbuatan baik yang dilakukan oleh tokoh maka penanaman karakter pada anak dikatakan berhasil. Selain itu, anak dapat mengimitasi bahasa yang digunakan dalam dongeng sehingga kemampuan bahasa meningkat dan perbendaharaan kata juga meningkat. Aktivitas dongeng ini dapat dilakukan kapanpun dan sangat mudah. Guru dapat melakukan aktivitas tersebut ketika mengawali pembelajaran ataupun di akhir pembelajaran. 


\section{B. Kecerdasan Bahasa}

Kecerdasan berbahasa ditandai dengan keterampilan menggunakan kata-kata sesuai dengan kaidah kebahasaan secara lisan maupun tertulis. Kecerdasan bahasa meliputi kecerdasan bunyi bahasa, kecerdasan pengolahan bahasa, kecerdasan memaknai bahasa kecerdasan praktis berbahasa. Menurut Kurniawan (2016:38-39) bahwa perkembangan bahasa berkaitan dengan kemampuan anak dalam menggunakan kode bahasa untuk mengungkapkan gagasan dan perasaan. Kecerdasan berbahasa berkaitan dengan:

1. Kemampuan mengolah kata-kata dalam berkomunikasi

2. Menguasai kosa kata dengan tepat dan bervariasi

3. Kemampuan mengungkapkan gagasan, ide, dan perasaan.

Kecerdasan bahasa harus diasah sejak dini saat usia balita oleh ibu karena pada masa ini anak mengalami pembelajaran kebahasaan misalnya bunyi bahasa dan merangkai bunyi bahasa menjadi kata. Pada masa ini, anak harus dibiasakan untuk diajarkan bermacam-macam kosa kata sehingga anak familiar dengan kata yang sering diperdengarkan. Selain itu, sampai usia SD anak juga harus selalu diajarkan pembelajaran bahasa yaitu pembelajaran kosa kata. Sehingga ketika dewasa, anak tersebut menjadi seseorang yang cerdas dalam hal kebahasaan.

\section{Dongeng sebagai Pembentuk Karakter}

Berbeda dengan para orang tua zaman dahulu yang tidak sibuk bekerja. Mereka memiliki lebih banyak waktu untuk memperhatikan perkembangan anaknya. Kebiasaan masyarakat zaman dahulu menggunakan kisah tradisional sebagai media untuk membentuk karakter bangsa dan memperbaiki karakter bangsa. Kisah-kisah tradisional ini digunakan sebagai media masyarakat zaman dahulu dalam suatu aktivitas yang disebut dengan mendongeng. Kisah tradisional yang diciptakan berupa pepatah, cerita rakyat, mitos, cerita binatang, fabel, dan legenda.

Sejalan dengan pemikiran Kurniawan (2016:8) bahwa dongeng memiliki karakteristik menyenangkan dan membangun. Dongeng sejak awal diciptakan dan dipahami membrikan kesenangan dan pendidikan bagi pendengarnya. Aktivitas mendongeng dapat menstimulus pendengar untuk merenungkan dan memikirkan hal-hal positif yang dapat dijadikan sebagai pedoman dalam kehidupan sehari-hari. Nenek 
moyang dalam menciptakan kisah tradisional sebagai media mendongeng dibalut dengan estetika bahasa sekaligus mengandung pendidikan karakter. Estetika bahasa ini sangat menghibur anak-anak dan dapat memberikan pembelajaran hidup kepada anak. Begitulah sastra anak yang awalnya bersifat menghibur namun pada dasarnya juga mendidik, sehingga harus mempertimbangkan perkembangan psikologis, pedagogis, dan segala lingkup kehidupan khasnya (Sarumpaet: 2010:12).

\section{Pembahasan}

Pembentukan karakter melalui aktivitas dongeng memberikan manfaat secara langsung. Manfaat tersebut yaitu (1) memberikan pendidikan dan pengalaman kehidupan bagi para siswa, (2) Membangun imajinasi dan daya penalaran para siswa, (3) menstimulus emosi para siswa, (4) melatih dan mengembangkan aspek lingual para siswa, (5) membangun ikatan batin antara guru dan siswa, (6) menghibur para siswa. Aktivitas mendongeng harus ditrasformasi dengan baik melalui gairah mendongeng dan melalui media pendukung yang baik agar pesan dongeng tersampaikan dengan baik dan situasi aktivitas mendongeng menjadi bergelora.

Selain penumbuhan karakter, dongeng juga mampu menumbuhkan kecerdasan bahasa yang meliputi keterampilan menyimak, keterampilan menulis, keterampilan membaca dan keterampilan berbicara. Tujuan mengembangkan kecerdasan berbahasa anak yaitu 1) menumbuhkan kemampuan berbahasa yang baik melalui tulisan dan lisan, 2) menumbuhkan kemampuan komunikasi anak yang baik dalam hal ajakan, 3) terampil dalam hal menghafal dan ingatan, 4) mampu menguraikan maksud dan keinginan serta ketika menjelaskan, 5) mampu mengolah bahasa anak secara mandiri (Kurniawan, 2016:73)

Sebelum melakukan aktivitas mendongeng, perlu adanya pemilihan dongeng yang baik untuk perkembangan siswa yang disesuaikan dengan usia. Pemilihan dongeng sesuai dengan kebutuhan anak yang ditinjau dari tema, alur, tokoh, setting, sudut pandang, amanat dan gaya bahasa (Hudhana, 2018:6) Berikut ini merupakan hal-hal yang harus diperhatikan dalam memilih dongeng:

1. Pilihlah dongeng yang sesuai dengan usia siswa,

2. Dongeng yang akan digunakan harus dongeng yang dapat menghibur sekaligus memberikan nilai pendidikan kepada siswa, 
3. Gunakan dongeng yang mengandung bahasa yang baik dan sesuai dengan tingkat pemahaman siswa,

4. Pilihlah dongeng yang durasi waktuya sesuai dengan minat siswa sehingga tidak menimbulkan kebosanan,

5. Dongeng dapat dimodifikasikan namun harus memperhatikan siswa dari segi psikologi, emosional dan perkembangan siswa.

Aktivitas mendongeng dilakukan dengan bahasa yang baik dan pemilihan dongeng harus sesuai dengan perkembangan siswa. Mengingat usia siswa Sekolah Dasar yang masih cenderung mengimitasi apapun yang dilihat. Apabila dalam aktivias mendongeng digunakan bahasa yang baik maka kemampuan lingual para siswa akan menjadi baik. Selain itu, pemilihan dongeng yang sesuai dengan perkembangan siswa dapat mempengaruhi perkembangan psikologi dan emosional siswa. Aktivitas mendongeng untuk membentuk karakter dan kecerdasan berbahasa dapat dilakukan dengan tahap berikut:

1. Tentukan dahulu tujuan dilakukannya aktivitas mendongeng untuk apa, sehingga aktivitas ini tepat pada sasaran. Tujuan digunakan agar dongeng yang akan diajarkan mampu mengenai sasaran audien yaitu siswa Sekolah Dasar. Tujuan dongeng dapat meliputi: a) tujuan kecerdasaan bahasa yaitu untuk meningkatkan penguasaan kosakata baru, meningkatkan kemampuan berbahasa yang meliputi empat keterampilan bahasa, mampu menguasai pemahaman mengenai amanat dan pesan cerita, dan mampu berbahasa dengan baik secara tertulis dan lisan; b) tujuan pendidikan karakter yaitu meningkatkan pemahaman mengenai karakter positif, memberikan pengalaman dan pembelajaran hidup, membentuk karakter yang kuat dan memberikan solusi permasalahan kehidupan.

2. Tentukan tema dongeng dan materi dongeng yang akan digunakan untuk aktivitas mendongeng, Tema dan materi dongeng tentunya disesuaikan dengan kebutuhan dan usia anak. Hal-hal yang perlu diperhatikan dalam menentukan tema dan materi dongeng untuk anak:

a. Sesuaikan dengan tumbuh kembang anak sehingga anak tidak mengalami dewasa sebelum waktunya.

b. Tentukan dongeng yang banyak menampilkan karakter positif. 
c. Carilah dongeng yang menggunakan bahasa-bahasa yang akrab dengan anak sehingga anak tidak kesulitan untuk memahami dongeng.

d. Dongeng yang akan digunakan usahakan dongeng yang beralur maju dan konfiknya sederhana.

3. Tentukan media pendukung dalam mendongeng yang efektif dan efisien serta menarik perhatian siswa sehingga mereka merasa tertarik dan muncul rasa keingintahuan, Media yang digunakan dapat berupa media gambar, boneka maupun wayang. Gunakan media yang mudah dalam aplikasnya dan disesuaikan dengan perkembangan anak.

4. Lakukanlah aktivitas mendongeng dengan menggunakan intonasi dan gesture tubuh sehingga menarik perhatian siswa untuk mendengarkan dongeng dengan seksama. Kuasai panggung dan gunakan segala gerak yang dapat mengundang minat anak agar perhatian anak terpusat pada pendongeng. Namun, jangan terlalu banyak melakukan gerakan yang dirasa tidak perlu.

5. Lakukan kegiatan tanya jawab berkaitan dengan dongeng agar terjadi interaksi antara guru dan siswa, Tanya jawab ini berfungsi untuk merangsang daya pemikiran anak dan pemahaman anak yang berkaitan dengan isi dongeng. Tanyakan hal-hal yang berkaitan dengan karakter dan kosa kata baru kepada anak sehigga dapat diketahui sejauh mana pemahaman anak.

6. Menyampaikan pesan dan amanat secara langsung kepada siswa agar pesan yang terdapat dalam dongeng tersampaikan secara maksimal. Hal ini dapat mencegah ketidakpahaman atau kesalahpahaman anak dalam menangkap pembelajaran dan pengalaman hidup yang ada di dalam dongeng tersebut.

\section{E. Simpulan}

Aktivitas mendongeng merupakan aktivitas yang penting dilakukan oleh orang tua maupun guru pada siswa Sekolah Dasar. Oleh karena, dongeng mengandung pendidikan karakter dan pembelajaran kebahasaan. Pemilihan dongeng harus melihat ketentuan: 1) Pilihlah dongeng yang sesuai dengan usia siswa, 2) Dongeng yang akan digunakan harus dongeng yang dapat menghibur sekaligus memberikan nilai pendidikan kepada siswa, 3) Gunakan dongeng yang mengandung bahasa yang baik dan sesuai dengan tingkat pemahaman siswa, 4) Pilihlah dongeng yang durasi waktuya sesuai dengan 
minat siswa sehingga tidak menimbulkan kebosanan. Dongeng dapat dimodifikasikan namun harus memperhatikan siswa dari segi psikologi, emosional dan perkembangan siswa.Langkah-langkah mendongeng untuk kecerdasan bahasa dan pendidikan karakter yaitu: 1) tentukan tujuan dilakukannya aktivitas mendongeng untuk apa, sehingga aktivitas ini tepat pada sasaran, 2) Tentukan tema dongeng dan materi dongeng yang akan digunakan untuk aktivitas mendongeng, 3) Tentukan media pendukung dalam mendongeng yang efektif dan efisien serta menarik perhatian siswa, 4) lakukan aktivitas mendongeng dengan menggunakan intonasi dan gesture tubuh, 5) lakukan kegiatan tanya jawab berkaitan dengan dongeng agar terjadi interaksi antara guru dan siswa, 6) menyampaikan pesan dan amanat secara langsung kepada siswa.

\section{F. Daftar Pustaka}

Hudhana, Winda Dwi. 2015. Pengenalan Budaya dan Pembentukan Karakter Melalui Folklor pada Anak Usia Dini. Jurnal Inasnia:Jurnal Kependidikan Volume 20 No 1 Januari-Juni 2015 pp 114-122 2018. Pembelajaran Sastra untuk Sekolah Dasar. Tangerang: Mahara Publishing

Kurniawan, Heru. 2016. Kreatif Mendongeng untuk Kecerdasan Jamak Anak. Jakarta: Kencana

Sarumpaet, Riris K. Toha. 2010. Pedoman Penelitian Sastra Anak. Jakarta: Yayasan Pustaka Obor Indonesia 